\title{
DOES CONCENTRATION OF OWNERSHIP AND FAMILY CONTROL AFFECT SPECIALISATION/DIVERSIFICATION BUSINESS STRATEGIES?
}

\author{
Alejandro Hernández-Trasobares, Carmen Galve-Górriz
}

\section{Introduction}

Interest in diversification has largely focused on three topics: the way in which business diversification can be measured [19], [35], [48], [60], [69], the relationship between diversification and business results and the factors that determine diversification [4], [6], [11], [12], [17], [26], [27], [36], [41], [50], [58], [70], [71], [74], [72]. However, less attention has been paid to the impact of ownership structure (concentration and main shareholder) on degree of business diversification [13], [14], [16], [19], [30], [31], [63], [76]. Although some authors mention, in theoretical terms, the importance of concentration of ownership [2], [15], [30], [44] and the type of shareholder/s that effectively control the firm [19], [54] [55], [71], [75], in an analysis of business diversification, very few studies have analyzed empirically said impact, with exceptions focusing on the US, European and Asian corporations [3], [11], [15], [19], [25], [27], [29], [40], [58], [50], [74]. The results found in the literature regarding corporate diversification strategy are not conclusive, due to differences in the concept of diversification and measurements used for its study [5], [49].

This study shares the objective of learning more about corporate diversification strategies in relation to type of controlling shareholder or group, more specifically we study impact of ownership structure on degree and type of business diversification. The study differs in several ways, however, from previous research. First, we use data that is largely taken from the information supplied by firms to the Spanish Stock Market Commission (Comisión Nacional del Mercado de Valores). This should guarantee its reliability. Secondly, unlike most of the previous studies, in which the firm itself is the unit of analysis, our diversification study uses the pyramidal group of independent firms controlled by the same parent company; as most of the determinant factors of diversification are similar to the factors that explain the existence of pyramidal groups of firms, we believe that it is more pertinent to study type and degree of business diversification in relation to the entire group rather than the parent company (Bertrand, Johnson, Samphantarak and Schoar [7], Bru and Crespi [9], and Hernández and Galve [33]). Thirdly, we present comparisons of the growth strategies (diversification versus specialisation) adopted by business groups controlled by a family, by foreign capital, by a bank or several shareholders, none of which have effective control of the firm.

The paper is organized as follows: section 1 refers to the theoretical development of diversification covering the analysis of diversification from a pyramidal group perspective and the influence of ownership structure. Section 2 deals with research method, including the sample, the variables measurement and the methodology. Finally, section 3 presents the results and conclusions.

\section{Theoretical Development of Diversification: Group Pyramidal and Ownership Structure}

\subsection{Analysis of Diversification from a Pyramidal Group Perspective}

Diversification implies a firm moving into a number of markets (sectors, industries or segment) it was not previously engaged in. For several decades, product diversification has been a highly popular strategy among large and growing industrial firms in the industrialized world. Firm uses three main strategies to diversify across product segment like vertical integration, related diversification and unrelated diversification. 
Most of the studies on diversification have been focused on aspects such as the "extent" of diversification (i.e. less or more diversification), the "directions" (i.e. related or unrelated), and the "mode" (i.e. diversification via internal expansion or diversification via mergers and acquisitions of firms). Some empirical studies obtain that diversifying into related product-markets produces higher returns than diversifying into unrelated product-markets and less diversified firms performs better than highly diversified firms [64].

During the 60s and 70s, many companies used acquisitions of companies such as instrument for industrial diversification. The riskaverse firms minimized their risk by acquiring companies in other sectors, increasing their profits through greater economies of scale and scope. The success of diversification, using acquisitions as a means to diversify, is linked to a variety of factors such as company resources, legal and regulatory restrictions, and the macroeconomic environment. Moreover, the failure may be due to factors as diverse as the reason for purchase was not the acquisition of synergies but pursue personal interests of managers.

A review of the literature about factors explaining corporate diversification shows that most studies take the firm itself as their unit of analysis. As far as we know, there are very few studies that analyze pyramidal corporations. However, the development of international communications and information technologies in the last few years, together with the deregulation of economic and financial trade, has accelerated market and business globalisation, giving rise to a gap between firm size and the much larger size of the market. This need for a larger dimension in order to compete on increasingly globalised markets and the inability of firms to develop all the resources and capabilities required for success without help, leads firms to establish different arrangements with other firms in order to attain these targets. In such a changing situation, firms have become involved in complex processes of structural and organizational reforms, and there has been a heavy increase in pyramidal groups as organizations capable of finding balance between the flexibility provided by the market and the coordination and stability derives from activity insourcing.

Pyramidal groups are defined as organization in which legally independent enterprises are controlled by the same entrepreneur (the parent company) through an ownership chain. This study, in order to avoid a biased view of business decisions related to diversification strategy, the unit used for our analysis of diversification is a pyramidal group of companies. The reason is that most of the factors that determine diversification are similar to the factors that explain the existence of pyramidal groups of companies, so we believe that it is more pertinent to study type and degree of business diversification in relation to business groups rather than their parent companies.

The reasons for the formation of business groups can be divided into a) group members can satisfy their financing needs by making use of internal funds available in the group, b) group members can also overcome the inefficiencies of factor or supplementary service markets when the group is of companies each of which is involved in at least one of the activities in the value chain, and c) the group also enables its members to make use of the know-how and capability of other members, to access new technologies and to reduce risks. Furthermore, groups can also be created for much more obscure reasons related to obtaining private profits (through tunnelling strategies), tax evasion and the exercise of market power [57].

\subsection{Ownership Concentration, Family Control and Diversification: Theory and Research Hypotheses}

There is not much literature analysing the relationship between concentration of ownership and familial nature of last owner and type of diversification [29], [41], [54] and it is more common to find studied that investigate the impact of different types of diversification on performance. There are different alternatives [64], [65] and the most common are related and unrelated. Diversification in related businesses makes better use of economies of scale and scope, increasing the value created by the firm [66] and enabling said businesses to benefit from the firm's core activity and customer base [59]; related diversification makes better use of the business's core resources and skills [8] is less complex and incurs less costs. Unrelated diversification, however, increases the firm's market power [56], reducing income variability and the likelihood of bankruptcy [42] and benefiting from an internal capital market [66].

Many researchers have attempted to 
understand the applicability of several theories to approximate and explain firm's diversification behavior. The most commonly used approaches or theories in the study of diversification include:

a) Transaction Cost Theory and Industrial Economy Theory, which sustain that diversification is for external and market reasons (search for new market opportunities, reduce transaction costs when they exceed the cost of insourcing certain activities, search for market power). According to Transaction Cost Theory firms diversify their activities in response to the existence of unutilized resources and nature of these resources.

b) Resource and Capability Theory, according to which diversification is due to internal reasons (manager's ability to exploit commotions and discover new opportunities, availability of indivisible internal resources and public resources that can be used to obtain different products or provide services with the same efficacy).

In this paper we mainly use the Agency Theory approach, according to which diversification can be for efficiency, management or tunnelling reasons, depending on degree of concentration of ownership and type of controlling shareholder. Although there is evidence of the importance of ownership structure and family ownership in degree of diversification [3], [15], [16], [30], [31], [63], [71], results are by no means conclusive. Literature refers to both positive and negative effects of concentration of ownership and family ownership on degree and type of diversification.

The perspective of agency theory says that the greater concentration of ownership, the greater the risk assumed by said owners and the greater their interest in reducing said risk by diversification strategy [22], [73]. Other authors, however, believe that greater diversification with greater concentration of ownership is not to reduce risk but because the majority shareholders (who are in turn the firm's managers) are seeking greater profits and benefits even if it is at the expense of the wealth of minority shareholders (this is known as tunnelling, which is defines as the transfer of firm assets and profits to controlling owners) (agency problem type II) [15], [39], [43], [47], [74].

On the other hand, with regards to type of shareholder or controlling group, Shleifer and Vishny [69], Fama and Jensen [23] and Faccio,
Lang and Young [21] say that family firms have considerable incentives for minimising risk given the non-diverse nature of family investment. Corporate diversification is an attractive strategic option for family firms, as it enables them to mitigate risk, reducing income and result variability [20], [21], [71].

However, the studies conducted by Jensen [37], Jensen \& Murphy [38] and Hoskisson and Hitt [34] show that diversification is undertaken for managerial reasons (agency problem type I); the managers of firms with no controlling shareholders have economic and personal incentives to apply diversification strategies, even if it is detrimental for shareholders. Shleifer and Vishny [67] say that concentration of ownership is the most direct way in which to align the residual rights and control of external investors, limiting managerial discretionality and eliminating tunnelling-induced inefficiencies [68]. On the other hand, when a firm's managers are also shareholders, the more shares they own, the more their interests are in line with those of other shareholders, so there will be less diversification in the firm [6], [12], [17], [30]. In the specific case of family firms, the interests of family shareholders who are also managers will be in line with those of minority shareholders, so less diversification is to be expected [4], [19], [30], [51], [55], [71]. Friedland, Palmer and Stenbeck [24] show that family firms have less incentive to diversify for social and financial reasons. Diversification can endanger close personal relationships among family members, which could affect a firm's survival, which is one of its primary objectives: "to guarantee the firm's survival and long-term family control". Gómez-Mejía et al. [29] sustain that diversification involves a reduction in familial socio-emotional wealth (the negative effect of diversification on socio-emotional wealth is greater than its positive effect on reducing the concentration of risk, so family firms diversify less than non-family enterprises). On the other hand, diversification requires financial resources, which would weaken family control and increase financial risk if the firm decides to borrow [18].

With regards to deciding on one type of diversification, since the pioneer study by Rumelt [65], the literature generally refers to superior performance and productivity with related over unrelated diversification, with the former having a positive impact on performance 
[46], [61], while the later has a negative impact on results and productivity [6], [10]; Unrelated diversification is used by managers to satisfy personal interests and obtain higher income and greater prestige [68] to the detriment of maximisation of shareholder utility and the firm's value [17]. Some studies, however, consider that there are no differences between the two types of diversification [32], [41].

With regards to the impact of ownership structure on decisions concerning type of diversification, we have seen that the greater the concentration of ownership, the less discretionality that managers have [68], reducing investments in unrelated businesses in an attempt to reduce managers' personal risk [1] and the lower the agency costs involved [17], preferring related diversification strategies that have a positive impact on business performance and are more likely to create value [9]. On the other hand, depending on the type of controlling shareholder, family firms with significant concentration of ownership may prefer unrelated diversification, as it reduces the risks supported by the family [45] by reducing income and result volatility [21]. This strategy, however, requires the use of new resources and skills that makes it more difficult and complex [20]. Moreover, family firms attempt to maintain control over the business and to ensure its survival [54], so they tend to invest in activities associated to lower costs and less uncertainty, preferring related diversification strategies that preserve their socio-emotional wealth [28].

We also considered the possibility of firms preferring a mixed strategy, simultaneously combined related and unrelated diversification. Mixed diversification requires more resources and is more complicated from an organizational perspective, increasing agency and information costs [73], which have a negative impact on performance. In firms with non-family managers, they are expected to prefer mixed diversification, as this option enables them to spread out their personal risk and increase their power [1].

Therefore, the following hypotheses are contemplated:

$\mathrm{H} 1$ : Concentration of ownership favours a preference for a specialisation strategy rather than a diversification strategy.

$\mathrm{H} 2$ : Family-controlled firms show a greater preference for specialisation than non-family firms.
H3: Family firms show a greater preference for diversification the greater the concentration of family ownership.

H4: Concentration of ownership favours a preference for related diversification rather than mixed or unrelated strategies.

H5a: Family-controlled firms show a greater preference for related diversification than nonfamily enterprises.

H5b: Family-controlled firms show a lower preference for mixed diversification than nofamily enterprises.

H6: Family firms show a greater preference for unrelated diversification the greater the concentration of family ownership.

\section{Research Method}

\subsection{Sample}

The study starts with an initial sample of firms that traded on the Spanish stock markets in 2000-2005, operating in different sectors (the financial and energy sectors not are including because they have special regulations). Selection period is justified in the first place to avoid no comparative data since in 2007 a new law on takeover bids of companies takes effect [77]. The most important aspects introduced by the new law are the disappearing public offerings of mandatory partial acquisition (although there may be a voluntary basis) and will launch a mandatory tender offer for 100 percent of the capital of a company when it acquires at least 30 percent of voting rights or when participation increased by at least five per cent in less than 12 months. Furthermore, 2006 is not considered to be an atypical year, characterized as the period of greatest growth in sale and purchase of businesses (The number of mergers and acquisitions increased by 45 percent between 2005 and 2006 and the volume increases by nearly 70 percent) [77].

After eliminating firms for which all the information required for the study is not available, the final sample comprises 99 firms (594 observations). Specialisation and different types of diversification are determined from the annual reports supplied by the Stock Market Commission and the SABI-Informa database, which provides precise information about non-listed firms controlled by a listed parent company. Finally, the ownership information required to define a firm as a family firm or not, and to identify the last owner in non-family 
organizations, was obtained from the Stock Market Commission website and the SABIInforma database, occasionally resorting to secondary sources such as the media and the websites of the firms in the sample.

\subsection{Variables Measurement}

To measure degree of diversification, most studies only consider firm activities [3], [29], [41]. This study, however, considers the activities performed by the listed firm and those performed by the group of companies that it heads. This provides a more objective view of degree of diversification, as other studies ignore the activities of the firms that form part of the parent company's global strategy. Another reason for this analysis is the large number of family business groups in Spain. The study will thus obtain greater degrees of diversification than would be found if it only considered the parent company [11].

Following the Spanish General Accounting Plan, group companies are defined as firms over which the parent (listed) company has or could have direct or indirect effective control. According to the Spanish General Accounting Plan, control is defined as "when a (dominant) company is related to another (dependent) in any of the following ways:

(a) it holds a majority of voting rights;

(b) it is able to appoint or dismiss most of the members of the administrative body".

After analyzing the companies in each group, we analysed their annual accounts, using the SABI-Informa database when group companies are not listed. This information enables us to identify the activities of each firm, using the CNAE 93 Rev. 1 classification (Spanish Economic Activity Classification code that identifies and classifies company according to their economic activity; It is an adaptation of the European NACE and similar to the Standard Industrial Classification, SIC).

The study shows the possibility of combining different diversification strategies, considering three alternatives: specialisation, a single type of diversification (related or unrelated) and mixed strategies, which involve both related and unrelated diversification. Following are the diversification variables used in the study:

1. Specialisation (SPECIALISATION): dummy variable; value is one when the listed firm and its group companies perform the same/a single activity and zero otherwise (the company has diverse activities).
2. Pure related diversification (PURE REL. DIV.): dummy variable; value is one when the number of related activities performed by the listed firm and/or its business group is two or more and zero otherwise. Related activities are defined as activities with the same two digits in the CNAE 93 Rev. 1 classification, in which the last two are different; they are activities that require similar resources and capabilities.

3. Pure unrelated diversification (PURE UNREL. DIV.): dummy variable; the value is one when the number of unrelated activities performed by the listed firm and/or its business group is two or more and zero otherwise. Unrelated activities are defined as activities in which the first two digits are different, which do not require similar resources and capabilities and are not common activities that form part of the listed company's value chain.

4. Mixed diversification (MIXED DIV.): dummy variable; the value is one when the firm combines related (PURE REL. DIV.) and unrelated (PURE UNREL. DIV.) diversification strategies.

With regards to ownership variables, there are a significant number of different definitions used to define a family firm [52]. In this study, a company is a family firm (FAMILY) when the family owns (directly or indirectly) the largest share package and one or several family members are in key managerial positions and on the board of directors. Furthermore, to confirm a correct classification, we identified their last owners, analysing horizontal and vertical ownership chains to obtain the same results [43]. On the other hand, a firm's characterisation as a non-family enterprise also depends on the last owner's identity, distinguishing between three control groups:

a) Firms controlled by foreign capital (FOREIGN); the last owners are individuals or corporations that are non-residents in Spain.

b) Firms under financial control (FINANCIAL); the last owners are banks or investment funds.

c) Non effective control (NEC); an organization in which there is no single owner with effective control, as the shareholders own similar blocks of shares. A firm characterized as with non effective control (NEC) includes both a firm with multiple anonymous shareholders, none of whom hold a significant share, and a firm with a small number of shareholders with similar significant holdings. 
Degree of concentration of ownership is measured by the percentage of shares owned by the five largest shareholders (OWNERSHIP).

In line with previous research on the topic [3], [11], [29] we included the following control variables for the diversification study. We first considered firm size, measures by the logarithm of the total assets of the listed company (SIZE). Secondly, the age of the firm was established as the logarithm of the difference between two thousand and the year when the listed firm was established (AGE). Thirdly, the leverage of the listed firm was measured as the ratio between its total debts and total assets (LEVERAGE). Fourthly, investment in research and development was measures as the ratio between total intangible assets and total assets (R\&D). A dummy variable was also included, with a value of 1 when there had been a structural change in the listed firm, and 0 otherwise (SCD); this variable enabled us to control listed firms that had been involved in mergers and/or buyouts in 2000-2005, which could represent an important change in their degree or type of diversification.

\subsection{Methodology}

We first performed a descriptive study of the sample firms and the correlations between the different variables. Secondly, we examined the distribution of the firms in the sample according to diversification strategy, distinguishing between different types of firms attending to the nature of the shareholder of control. Finally, several binary logistic regression models were formulated for each of the dependent variables, to verify the validity of the models [62]. The SPSS 15.0 computer package was used throughout.

\section{Results and Discussion}

Table 1 shows the mean values, standard deviations and bilateral correlations between the variables used in the study. The data show that $24 \%$ of business groups prefer specialization, $20 \%$ prefer pure diversification strategies (18\% diversify in unrelated and $2 \%$ in related businesses) and more than half (56\%) prefer mixed diversification. These findings are consistent given that listed companies that are studied, which are characterized by a larger size and the employment of pyramidal groups to diversification. The bilateral correlations between the primary variables show that concentration of ownership is positively associated to specialization and pure related diversification and negatively associated to mixed diversification and firm size. Family control is positively correlated to concentration of ownership, specialization and pure related diversification and negatively correlated to mixed diversification. Firms with financial control or no effective control are negatively related to specialization and positively related to mixed diversification. There are, however, no significant correlations in specialization/ diversification preferences for firms controlled by foreign capital. Therefore, at first is observed as the highest ownership concentration and family character promote specialization and related diversification strategies, and decrease the likelihood of using mixed diversification strategies.

Table 2 shows the distribution of the firms in the sample according to diversification strategy, distinguishing between different types of firm with reference to type of controlling shareholder (last owner). The sample is dominated by family firms $(58.08 \%)$, followed by firms without effective control $(19.20 \%)$, financial firms $(15.92 \%)$ and, finally, firms controlled by foreign capital $(6.90 \%)$. The results show that, irrespective of who controls the company, $24 \%$ of the firms prefer specialization, more than half prefer mixed diversification (56.4\%) and only $19.7 \%$ choose pure diversification $(17.8 \%$ unrelated and only $1.9 \%$ related diversification). Secondly, in relation to the type of controlling shareholder, the data reveal differences, with family firms preferring specialization (32.5\%) and pure related diversification (2.9\%) more than non-family enterprises, and showing less preference for mixed diversification strategies $(47.5 \%)$. Ten of the eleven firms that only use related diversification are family businesses. Thirdly, in relation to non-family firms, we found that firms with no effective shareholder control present greater levels of pure unrelated diversification $(26.3 \%)$ and lower levels of specialization (7.9\%). Firms controlled by foreign capital or banks use similar diversification strategies.

Table 3 shows the results of the different binomial logistic models that explain the impact of concentration of ownership and type of controlling shareholder (last owner) on specialization and diversification strategies (distinguishing between pure unrelated 
and mixed diversification). There is no multicollinearity between the explanatory variables of any of the models [53].

When studying the impact of being a family firm on specialization/diversification, we not only considered family versus non-family enterprises, but also identified the last owner of the non-family organizations (distinguishing between firms controlled by foreign capital, under financial control and with no effective control), performing a more precise analysis of the Logit model. We also considered the interaction between family control and concentration of ownership in order to assess possible differences in the behaviour of families due to differences in concentration of ownership. The results of the specialization strategy models (models 1,3 and 4) reveal a positive impact of concentration of ownership on choice of this strategy, confirming $\mathrm{H} 1$ (results similar to those obtained by Amihud \& Lev [1] and Goranova et al. [30]). Ownership concentration allows aligning the residual rights and controlling external investors, limiting managerial discretionality (agency problem type I) [67].

On the other hand, with regards to type of principal shareholder, models 2, 3 and
4 show, firstly, that family-controlled firm use specialization (through their group of companies) more than non-family enterprises (controlled by foreign capital, by several shareholders none of whom control the firm alone and controlled by a bank), confirming $\mathrm{H} 2$ (results similar to those found by Anderson \& Reeb [3]; Gómez-Mejía et al. [29]). The interest of family shareholders will be in line with those of minority shareholders, the agency problem type I (manager vs. shareholders) will be less important, and the employment of diversification strategies will be decreased [4], [19], [55], [71].

Secondly, family firms with greater concentration of ownership specialize less than those with less concentration of ownership, confirming $\mathrm{H} 3$ and showing different behaviour by family firms depending on concentration of ownership [3], [51]. This may be because the greater concentration of family ownership, the greater the risk assumed by family members, and diversification strategy allows reducing said risk. Furthermore, greater ownership concentration facilitates the minority shareholders wealth expropriation by family (tunneling), appearing an agency problem type II [15], [39], [74]. Finally, with regards to firm size and involvement in mergers/acquisitions, they

\section{Tab. 1: Descriptive statistics and correlations between variables (rho de Spearman)}

\begin{tabular}{|c|c|c|c|c|c|c|c|c|c|c|c|c|c|c|c|c|c|}
\hline & MEAN & SD & 1 & 2 & 3 & 4 & 5 & 6 & 7 & 8 & 9 & 10 & 11 & 12 & 13 & 14 & 15 \\
\hline 1. OWNERSHIP & 57.24 & 24.78 & 1.00 & & & & & & & & & & & & & & \\
\hline 2. SIZE & 11.95 & 1.58 & $-0.115^{\star \star}$ & 1.000 & & & & & & & & & & & & & \\
\hline 3. AGE & 3.63 & 0.71 & 0.015 & 0.030 & 1.000 & & & & & & & & & & & & \\
\hline 4. LEVERAGE & 0.37 & 0.22 & 0.059 & $0.463^{\star \star}$ & $0.103^{*}$ & 1.000 & & & & & & & & & & & \\
\hline 5. R\&D & 0.03 & 0.08 & -0.030 & $0.280^{* \star}$ & -0.003 & $0.185^{\star \star}$ & 1.000 & & & & & & & & & & \\
\hline 6. DSC & 0.22 & 0.41 & 0.038 & $0.580^{\star *}$ & -0.034 & $0.203^{* *}$ & 0.044 & 1.000 & & & & & & & & & \\
\hline 7. FAMILY & 0.58 & 0.49 & $0.242^{\star \star}$ & $-0.324^{\star *}$ & $-0.103^{*}$ & -0.030 & $-0.127^{* *}$ & $-0.145^{* *}$ & 1.000 & & & & & & & & \\
\hline 8. FOREIGN & 0.07 & 0.25 & $0.098^{*}$ & $0.140^{* \star}$ & -0.004 & -0.079 & -0.030 & 0.014 & $-0.321^{* *}$ & 1.000 & & & & & & & \\
\hline 9. FINANCIAL & 0.16 & 0.36 & $-0.190^{* *}$ & $0.190^{\star \star}$ & -0.033 & 0.040 & 0.053 & $0.090 *$ & $-0.510^{* *}$ & $-0.118^{* *}$ & 1.000 & & & & & & \\
\hline 10. NCE & 0.19 & 0.39 & $-0.190 * *$ & $0.140^{\star *}$ & $0.162^{* \star}$ & 0.052 & $0.130^{* *}$ & $0.089^{*}$ & $-0.574^{* *}$ & $-0.133^{* *}$ & $\star-0.211^{* *}$ & * 1.000 & & & & & \\
\hline 11. SPECIALISATION & 0.24 & 0.42 & $0.234^{\star *}$ & $-0.524^{* *}$ & -0.008 & $-0.086^{*}$ & $-0.245^{* *}$ & $-0.290 * *$ & $0.236^{* \star}$ & -0.044 & $-0.092^{*}$ & $-0.183^{* *}$ & 1.000 & & & & \\
\hline 12. PURE DIV. & 0.20 & 0.04 & -0.010 & $-0.182^{* *}$ & -0.047 & $-0.176^{* *}$ & 0.076 & $-0.173^{* *}$ & 0.009 & -0.035 & $-0.087^{\star}$ & $0.092^{*}$ & $-0.278^{* *}$ & * 1.000 & & & \\
\hline 13. PURE REL. DIV. & 0.02 & 0.13 & $0.114^{\star *}$ & -0.062 & $-0.115^{\star *}$ & * -0.025 & $-0.102^{*}$ & 0.017 & $0.091^{*}$ & -0.037 & -0.060 & -0.035 & -0.077 & $0.277^{* *}$ & 1.000 & & \\
\hline 14. PUREUNREL.DN. & 0.18 & 0.38 & -0.050 & $-0.167^{\star *}$ & -0.008 & $-0.174^{* *}$ & $0.115^{\star \star}$ & $-0.186^{* *}$ & -0.023 & -0.023 & -0.070 & $0.108^{* *}$ & ${ }^{*}-0.261^{* *}$ & $* 0.941 * *$ & -0.064 & 1.000 & \\
\hline 15. MIXED DIV. & 0.56 & 0.49 & $-0.194^{* *}$ & $\star 0.597^{* \star}$ & 0.045 & $0.216^{\star *}$ & $0.150^{* *}$ & $0.388^{* *}$ & $-0.210^{* *}$ & 0.065 & $0.149^{* *}$ & $0.084^{*}$ & $-0.637^{* *}$ & $*-0.563^{* *}$ & $-0.156^{\star \star}$ & $-0.530^{* *}$ & 1.000 \\
\hline
\end{tabular}

${ }^{*} p<.10 .{ }^{* *} p<.05 .{ }^{* * *} p<.01$ 


\begin{tabular}{l|c|c|c|c|c|c|c|c|c|c|c}
\multirow{2}{*}{} & \multicolumn{2}{|c|}{ TOTAL } & \multicolumn{2}{c|}{ FAMILY } & \multicolumn{2}{c|}{ FOREIGN } & \multicolumn{2}{c|}{ FINANCIAL } & \multicolumn{2}{c|}{ NCE } & \multirow{2}{*}{ Chi-squared } \\
\cline { 2 - 13 } & $\mathbf{N}$ & $\%$ & $\mathbf{N}$ & $\%$ & $\mathbf{N}$ & $\%$ & $\mathbf{N}$ & $\%$ & $\mathbf{N}$ & $\%$ & \\
\hline 1. SPECIALISATION & 142 & 23.9 & 112 & 32.5 & 7 & 17.1 & 14 & 14.9 & 9 & 7.9 & $35.205^{* * *}$ \\
\hline 2. PURE DIV. & 117 & 19.7 & 69 & 20.0 & 6 & 14.6 & 11 & 11.7 & 31 & 27.2 & $8.533^{* *}$ \\
\hline 2.1 PURE REL. DIV. & 11 & 1.9 & 10 & 2.9 & - & --- & - & --- & 1 & 0.9 & 5.223 \\
\hline 2.2 PURE UNREL. DIV & 106 & 17.8 & 59 & 17.1 & 6 & 14.6 & 11 & 11.7 & 30 & 26.3 & $8.147^{* *}$ \\
\hline 3. MIXED DIV. & 335 & 56.40 & 164 & 47.5 & 28 & 68.3 & 69 & 73.4 & 74 & 64.9 & $27.793^{* * *}$ \\
\hline TOTAL & 594 & 100 & 345 & 58.08 & 41 & 6.90 & 94 & 15.82 & 114 & 19.20 &
\end{tabular}

${ }^{*} p<.10 .{ }^{* *} p<.05 .{ }^{* * *} p<.01$

Source: own

\begin{tabular}{|c|c|c|c|c|c|c|c|c|c|c|c|c|}
\hline \multirow[t]{3}{*}{ Tab. 3: } & \multicolumn{12}{|c|}{$\begin{array}{l}\text { Binomial Logit: Specialisation, Mixed Diversification } \\
\text { and Pure Unrelated Diversification }\end{array}$} \\
\hline & \multicolumn{4}{|c|}{ SPECIALISATION } & \multicolumn{4}{|c|}{ MIXED DIVERSIFICATION } & \multicolumn{4}{|c|}{ PURE UNRELATE DIVERSIFICATION } \\
\hline & $\begin{array}{l}\text { (1) } \beta \text {-coef } \\
\text { (wald) }\end{array}$ & $\begin{array}{l}\text { (2) } \beta \text {-coef } \\
\text { (wald) }\end{array}$ & $\begin{array}{l}\text { (3) } \beta \text {-coef } \\
\text { (wald) }\end{array}$ & $\begin{array}{l}\text { (4) B-coef } \\
\text { (wald) }\end{array}$ & $\begin{array}{l}\text { (5) } \beta \text {-coef } \\
\text { (wald) }\end{array}$ & $\begin{array}{l}\text { (6) } \beta \text {-coef } \\
\text { (wald) }\end{array}$ & $\begin{array}{l}\text { (7) B-coef } \\
\text { (wald) }\end{array}$ & $\begin{array}{l}\text { (8) } \beta \text {-coef } \\
\text { (wald) }\end{array}$ & $\begin{array}{l}\text { (9) } \beta \text {-coef } \\
\text { (wald) }\end{array}$ & $\begin{array}{l}\text { (10) } \beta \text {-coef } \\
\text { (wald) }\end{array}$ & $\begin{array}{l}\text { (11) } \beta \text {-coef } \\
\text { (wald) }\end{array}$ & $\begin{array}{l}\text { (12) } \beta \text {-coef } \\
\text { (wald) }\end{array}$ \\
\hline CONSTANT & $\begin{array}{c}10.386^{* \star *} \\
(40.713)\end{array}$ & $\begin{array}{l}10.575^{* * *} \\
(36.732)\end{array}$ & $\begin{array}{l}9.379^{* \star *} \\
(26.913)\end{array}$ & $\begin{array}{l}8.924^{* * *} \\
(23.712)\end{array}$ & $\begin{array}{c}-11.421^{* * *} \\
(64.513)\end{array}$ & $\begin{array}{c}-12.331^{* * *} \\
(66.298)\end{array}$ & $\begin{array}{c}-11.443^{\star \star *} \\
(55.269)\end{array}$ & $\begin{array}{c}-11.513^{* * \star} \\
(54.681)\end{array}$ & $\begin{array}{l}-0.826 \\
(0.430)\end{array}$ & $\begin{array}{l}-0.074 \\
(0.003)\end{array}$ & $\begin{array}{c}0.136 \\
(0.010)\end{array}$ & $\begin{array}{c}0.415 \\
(0.086)\end{array}$ \\
\hline $\begin{array}{l}\text { OWNER- } \\
\text { SHIP }\end{array}$ & $\begin{array}{l}2.505^{\star * \star} \\
(18.767)\end{array}$ & & $\begin{array}{l}2.110^{* \star *} \\
(11.300)\end{array}$ & $\begin{array}{l}3.946^{\star \star *} \\
(12.848)\end{array}$ & $\begin{array}{c}-1.790^{\star \star *} \\
(14.711)\end{array}$ & & $\begin{array}{c}-1.937^{* \star *} \\
(13.885)\end{array}$ & $\begin{array}{l}-3.365^{\star \star \star} \\
(21.543)\end{array}$ & $\begin{array}{l}-0.499 \\
(1.177)\end{array}$ & & $\begin{array}{l}-0.281 \\
(0.311)\end{array}$ & $\begin{array}{c}0.940 \\
(1.853)\end{array}$ \\
\hline FAMILY & & $\begin{array}{l}1.362^{* * *} \\
(10.026)\end{array}$ & $\begin{array}{l}0.869^{* *} \\
(3.881)\end{array}$ & $\begin{array}{c}2.346^{* * *} \\
(7.801)\end{array}$ & & $\begin{array}{l}-0.142 \\
(0.231)\end{array}$ & $\begin{array}{l}0.155 \\
(0.264)\end{array}$ & $\begin{array}{c}-1.521^{* *} \\
(5.594)\end{array}$ & & $\begin{array}{c}-0.762^{* * *} \\
(6.760)\end{array}$ & $\begin{array}{c}-0.714^{* *} \\
(5.468)\end{array}$ & $\begin{array}{c}0.645 \\
(1.132)\end{array}$ \\
\hline FOREIGN & & $\begin{array}{l}1.842^{\star \star \star} \\
(8.802)\end{array}$ & $\begin{array}{c}0.976 \\
(2.194)\end{array}$ & $\begin{array}{c}0.345 \\
(0.232)\end{array}$ & & $\begin{array}{l}-0.249 \\
(0.293)\end{array}$ & $\begin{array}{c}0.406 \\
(0.669)\end{array}$ & $\begin{array}{c}0.788 \\
(2.268)\end{array}$ & & $\begin{array}{l}-0.904^{*} \\
(3.116)\end{array}$ & $\begin{array}{l}-0.815 \\
(2.319)\end{array}$ & $\begin{array}{l}-1.143^{* *} \\
(4.154)\end{array}$ \\
\hline FINANCIAL & & $\begin{array}{l}1.382^{* *} \\
(6.435)\end{array}$ & $\begin{array}{l}1.144^{* *} \\
(4.155)\end{array}$ & $\begin{array}{l}0.983^{*} \\
(2.755)\end{array}$ & & $\begin{array}{c}0.208 \\
(0.295)\end{array}$ & $\begin{array}{c}0.139 \\
(0.126)\end{array}$ & $\begin{array}{c}0.035 \\
(0.008)\end{array}$ & & $\begin{array}{c}-1.032^{\star *} \\
(6.421)\end{array}$ & $\begin{array}{c}-1.036^{* *} \\
(6.433)\end{array}$ & $\begin{array}{c}-1.017^{* *} \\
(6.269)\end{array}$ \\
\hline $\begin{array}{l}\text { OWNER- } \\
\text { SHIP* } \\
\text { FAMILY }\end{array}$ & & & & $\begin{array}{l}-2.860^{* *} \\
(4.442)\end{array}$ & & & & $\begin{array}{c}3.020^{* * *} \\
(8.815)\end{array}$ & & & & $\begin{array}{l}-2.646^{* *} \\
(6.604)\end{array}$ \\
\hline SIZE & $\begin{array}{c}-1.350^{* * \star} \\
(83.913)\end{array}$ & $\begin{array}{c}-1.393^{* * *} \\
(87.202)\end{array}$ & $\begin{array}{l}-1.345^{* * *} \\
(77.294)\end{array}$ & $\begin{array}{c}-1.367^{* * *} \\
(79.653)\end{array}$ & $\begin{array}{l}1.095^{* * *} \\
(84.530)\end{array}$ & $\begin{array}{l}1.109^{* * *} \\
(83.493)\end{array}$ & $\begin{array}{l}1.084^{* * *} \\
(76.555)\end{array}$ & $\begin{array}{l}1.150^{* * *} \\
(79.662)\end{array}$ & $\begin{array}{l}0.010 \\
(0.011)\end{array}$ & $\begin{array}{c}0.017 \\
(0.028)\end{array}$ & $\begin{array}{c}0.005 \\
(0.002)\end{array}$ & $\begin{array}{l}-0.046 \\
(0.192)\end{array}$ \\
\hline AGE & $\begin{array}{c}0.352 \\
(2.691)\end{array}$ & $\begin{array}{l}0.486^{* *} \\
(4.926)\end{array}$ & $\begin{array}{l}0.460^{* \star} \\
(4.229)\end{array}$ & $\begin{array}{l}0.419^{*} \\
(3.389)\end{array}$ & $\begin{array}{l}-0.036 \\
(0.055)\end{array}$ & $\begin{array}{l}-0.084 \\
(0.281)\end{array}$ & $\begin{array}{l}-0.019 \\
(0.014)\end{array}$ & $\begin{array}{c}0.017 \\
(0.010)\end{array}$ & $\begin{array}{c}0.079 \\
(0.221)\end{array}$ & $\begin{array}{l}-0.040 \\
(0.055)\end{array}$ & $\begin{array}{l}-0.031 \\
(0.032)\end{array}$ & $\begin{array}{l}-0.106 \\
(0.354)\end{array}$ \\
\hline LEVERAGE & $\begin{array}{l}2.979 * \star \star \\
(16.933)\end{array}$ & $\begin{array}{l}3.220^{* * *} \\
(21.151)\end{array}$ & $\begin{array}{l}2.978^{\star \star \star} \\
(16.715)\end{array}$ & $\begin{array}{l}2.982^{\star * \star} \\
(3.389)\end{array}$ & $\begin{array}{l}-0.472 \\
(0.695)\end{array}$ & $\begin{array}{l}-0.773 \\
(1.964)\end{array}$ & $\begin{array}{l}-0.425 \\
(0.547)\end{array}$ & $\begin{array}{l}-0.663 \\
(1.308)\end{array}$ & $\begin{array}{c}-1.869^{\star \star \star} \\
(9.613)\end{array}$ & $\begin{array}{c}-1.894^{* \star \star} \\
(9.927)\end{array}$ & $\begin{array}{c}-1.831^{* * *} \\
(8.973)\end{array}$ & $\begin{array}{c}-1.733^{* \star *} \\
(8.023)\end{array}$ \\
\hline$S C D$ & $\begin{array}{l}-2.300^{\star *} \\
(4.778)\end{array}$ & $\begin{array}{l}-1.738^{*} \\
(2.758)\end{array}$ & $\begin{array}{c}-2.213^{* \star} \\
(4.355)\end{array}$ & $\begin{array}{l}-2.119^{* *} \\
(4.038)\end{array}$ & $\begin{array}{l}1.241^{\star * \star} \\
(8.960)\end{array}$ & $\begin{array}{l}0.822^{* *} \\
(4.350)\end{array}$ & $\begin{array}{c}1.322^{\star * \star} \\
(9.508)\end{array}$ & $\begin{array}{l}1.274^{\star * *} \\
(8.644)\end{array}$ & $\begin{array}{l}-1.577^{\star \star *} \\
(10.587)\end{array}$ & $\begin{array}{c}-1.715^{\star \star \star} \\
(12.664)\end{array}$ & $\begin{array}{c}-1.664^{\star * *} \\
(11.464)\end{array}$ & $\begin{array}{l}-1.658^{* \star *} \\
(10.997)\end{array}$ \\
\hline R\&D & $\begin{array}{c}2.433 \\
(2.003)\end{array}$ & $\begin{array}{c}2.440 \\
(2.290)\end{array}$ & $\begin{array}{c}2.905 \\
(2.618)\end{array}$ & $\begin{array}{l}3.680^{*} \\
(3.829)\end{array}$ & $\begin{array}{c}-3.833^{\star *} \\
(6.441)\end{array}$ & $\begin{array}{c}-3.134^{* \star} \\
(4.167)\end{array}$ & $\begin{array}{c}-3.686^{* *} \\
(5.896)\end{array}$ & $\begin{array}{c}-4.683^{\star \star \star} \\
(8.708)\end{array}$ & $\begin{array}{c}1.672 \\
(1.873)\end{array}$ & $\begin{array}{c}1.234 \\
(0.975)\end{array}$ & $\begin{array}{l}1.181 \\
(0.873)\end{array}$ & $\begin{array}{c}1.967 \\
(2.330)\end{array}$ \\
\hline $\mathbf{N}$ & 594 & 594 & 594 & 594 & 594 & 594 & 594 & 594 & 594 & 594 & 594 & 594 \\
\hline $\begin{array}{l}\text { Likelihood } \\
\text { Ratio }\end{array}$ & 394.537 & 400.762 & 389.082 & 384.485 & 527.385 & 541.134 & 526.693 & 517.549 & 511.250 & 503.227 & 502.916 & 496.239 \\
\hline Chi-square & $248.755^{\star * *}$ & $242.531^{* * *}$ & $254.210^{\star \star \star}$ & $258.807^{* \star \star}$ & $273.800^{* \star \star}$ & $260.052^{\star * *}$ & $274.493^{* \star \star}$ & $283.636^{* \star \star}$ & $41.998^{* * *}$ & $50.021^{\star \star *}$ & $50.331^{\star \star \star *}$ & $57.009^{* * *}$ \\
\hline $\begin{array}{l}\text { R2 Cox and } \\
\text { Snell }\end{array}$ & 0.347 & 0.340 & 0.353 & 0.358 & 0.374 & 0.359 & 0.375 & 0.385 & 0.069 & 0.082 & 0.083 & 0.093 \\
\hline $\begin{array}{l}\text { R2 Nagel- } \\
\text { kerske }\end{array}$ & 0.520 & 0.509 & 0.529 & 0.536 & 0.501 & 0.481 & 0.502 & 0.515 & 0.113 & 0.134 & 0.135 & 0.152 \\
\hline $\begin{array}{l}\text { Corrected } \\
\text { classified }\end{array}$ & $85.1 \%$ & $83.9 \%$ & $85.4 \%$ & $85.1 \%$ & $81.7 \%$ & $80.8 \%$ & $80.7 \%$ & $80.8 \%$ & $82.2 \%$ & $81.8 \%$ & $82.0 \%$ & $82.2 \%$ \\
\hline
\end{tabular}

${ }^{*} p<.10 .{ }^{* *} p<.05 .{ }^{* * *} p<.01$ 
are negatively related to specialization (similar results to those obtained by Anderson \& Reeb [3], Gómez-Mejía et al. [29] for size and by Miller et al. [55] for the merger/acquisition variable).

Table 3 also analyses the impact of concentration of ownership and family nature of business on diversification, with firms preferring pure (only one type of related or unrelated diversification) or mixed diversification (firms diversify their activities in related or unrelated manners). None of the firms that use pure related diversification are controlled by foreign agents or banks (Tab. 2), confirming partially $\mathrm{H} 5 \mathrm{a}$ (is not possible to make a binomial logistic model). The results of the complete mixed diversification model (model 8) show a negative impact of concentration of ownership on the choice of this type of strategy, confirming $\mathrm{H} 4$. The greater ownership concentration, the less discretionality that managers have [68], reducing agency problem type I (lower agency costs [16]), and decreasing investments in unrelated businesses, preferring related diversification strategies that have a positive impact on business performance [9].

On the other hand, the data reveal that family firms prefers mixed diversification less than non-family enterprises (confirming $\mathrm{H} 5 \mathrm{~b}$ ), because these strategies are associate to higher costs and more uncertainty, which can decrease socio-emotional wealth [28]. Moreover, mixed diversification strategies require the use of new resources and skills which may not own family firm [28].

However, family firms with greater concentration of ownership prefer mixed diversification strategies more than family businesses with less concentration of ownership (confirming H6). Family firms with significant concentration of ownership may prefer mixed diversification, as it reduces the risks supported by the family [45] by reducing income and result volatility [21]. Moreover, the higher family ownership the higher probability of occurrence of agency problem type II (majority shareholder vs. minority shareholder).

The models explain specialization and mixed diversification very well, although not unrelated diversification strategies, presumably due to the very small number of firms controlled by foreign capital (6) or banks (11) that choose this strategy.

\section{Conclusion}

This study aims to characterise and analyse the impact of ownership structure on specialization and diversification strategies (distinguishing between related, unrelated and mixed diversification), according to both concentration of ownership and type of controlling shareholder. The study is not only original because it studies diversification in relation to ownership structure, but because it also analyses diversification using corporate groups rather than parent companies. After selecting a representative sample of the leading companies trading on the Spanish stock exchange, we tested our hypotheses using binomial logistic regression and different statistical tests. Family firms represent more than half the firms in the sample, followed in order of importance by firms where no single shareholder has effective control (less than $25 \%$ in 2005), firms under financial control (around $12 \%$ of the sample) and firms controlled by foreign capital (less than 10\%).

The results show the importance of the ownership structure on diversification strategy adopted by the business group [15], [19], [30], [31], [63], [76], [16]. We test how ownership concentration and family control have a positive impact on the decision to specialize. The higher ownership concentration decrease agency cost, due to alignment between majority shareholders and minority shareholders interest. Higher ownership concentration solves agency problem type I, that is, reduces discretionary power of managers and decrease diversification (increase specialization) [30], [34], [68]. Also family firms adopt specialization strategies due to diversification can damage socio-emotional wealth [29] or family firm does not have the resources needed to carry out new activities [10]. However, greater family control (higher ownership concentration) decrease specialization. This may be due to appearance of tunneling, where family shareholders are seeking greater profits and benefits even if it is at the expense of the wealth of minority shareholders (agency problem type II) [15], [39], [74].

When considering the type of diversification strategy, we found that ownership concentration presents a negative impact on mixed diversification. Lower ownership concentration increase manager discretionality, so managers will use mixed diversification strategies to decrease personal risk and 
obtain higher income and greater prestige [68]. Higher ownership concentration will decrease manager discretionality and therefore mixed diversification strategies will be less used. Family firms use more related diversification strategies and less mixed diversification than non-family firms. Family firms try to ensure firm survival and select those strategies that maintain socio-emotional wealth and/or allow value creation [28], [55]. This causes a preference for related diversification, which generally has a positive impact on performance [61] with respect mixed and unrelated diversification. Unrelated and mixed diversification strategies require more resources and involve higher agency and information costs [73], which have a negative impact on performance. However, greater family control favors the use of mixed strategies that may be due to decrease family risk [42] or the appearance an agency problem type II and tunneling practices.

Also, firms not controlled by a single shareholder (SCD) present the greatest levels of diversification, particularly unrelated, and minimally choose specialization. These firms are characterized by higher manager discretionality (agency problem type I), therefore managers will adopt diversification strategies that will reduce managers personal risk and increase their power [1] These organizations have the lowest levels of concentration of ownership. Finally, firms controlled by banks and/or foreign capital present intermediate values in the control variables and diversification strategies. Concluding, the higher differences in diversification strategies are established between family firms (higher ownership concentration) and firms no controlled by a single shareholder (lower ownership concentration). In family firms, when ownership concentration is high, it may appear an agency problem type II [70].

The study is a first approach to the relationship between ownership structure, family nature and diversification. The diversification variables are dummies and it would be interesting to use other alternative measures such as entropy [60], more appropriately weighting degree of total, related and unrelated diversification. This would also use more statistically advanced and precise methods that would be able to confirm the results obtained here. The models also show the importance of analysing the last owner of non-family firms, as it can affect the significance of the results obtained (in this paper, it reaffirms the consistency of the models and results).

Future research should study the relationship between performance and productivity according to ownership structure and type of diversification, according to the last owner. There are very few studies [29], [41] and further research is required. Likewise, the development of a special type of diversification, vertical integration (performance of related value chain activities, before or after each other) could be considered; it has hardly been considered in the literature [41], [66] or it has been considered as a type of related diversification, a legal development with an impact on ownership structure and degree of diversification.

This paper is part of the results obtained in the framework of the research project Eco200913158 financed by Ministerio de Ciencia e Innovación and the CREVALOR Group of Research, acknowledged and financed by DGA-FSE.

\section{References}

[1] AMIHUD, Y., LEV, B. Risk reduction as a managerial motive for conglomerate mergers. Bell Journal of Economics. 1981, Vol. 12, Iss. 2, pp. 605-617. ISSN 0361-915X. DOI: 10.2307/3003575.

[2] AMIHUD, Y., LEV, B. Does corporate ownership structure affects its strategy towards diversification? Strategic Management Journal. 1999, Vol. 20, Iss. 11, pp. 10631069. ISSN 0143-2095. DOI: 10.1002/ (SICI)1097-0266(199911)20:11<1063::AIDSMJ69>3.0.CO;2-S.

[3] ANDERSON, R.C., REEB, D.M. FoundingFamily Ownership, Corporate Diversification and Firm Leverage. Journal of Law and Economics. 2003, Vol. 46, Iss. 2, pp. 653-684. ISSN 0022-2186. DOI: 10.1086/377115.

[4] ANDERSON, R.C., MANSI, S., REEB, D. Ownership structure and corporate decisionmaking. Journal of Economics and Business. 2007, Vol. 59, Iss. 5, pp. 355-357. ISSN 01486195. DOI: 10.1016/j.jeconbus.2007.04.001.

[5] BENITO, D., GUERRAS-MARTÍN, L.A., ZUÑIGA, J.A. Four Decades of Research on Product Diversification: A Literature Review. Management Decision. 2012, Vol. 50, 
Iss. 2, pp. 325-344. ISSN 0025-1747. DOI: 10.1108/00251741211203597.

[6] BERGER, P., OFEK, E. Diversification's effect on firm value. Journal of Financial Economics. 1995, Vol. 37, Iss. 1, pp. 3965. ISSN 0304-405X. DOI: 10.1016/0304405X(94)00798-6.

[7] BERTRAND, M., et al. Mixing family with business: a study of thai business groups and the family behind them. NBER working paper, January, 2008. ISSN 0898-2937. DOI: 10.3386/ w13738.

[8] BETTIS, R.A. Performance differences in related and unrelated diversified firms. Strategic Management Journal. 1981, Vol. 2, Iss. 4, pp. 379-393. ISSN 0143-2095. DOI: 10.1002/ smj.4250020406.

[9] BRU, L., CRESPI, R. Diversification of family business groups and board control [online]. Universitat de les Illes Balears, 200611-05 [cit. 2013-05-15]. Working paper. 23 p. (PDF). Available from: http://ssrn.com/ abstract $=924845$.

[10] CHANG, S., WANG, C. The effect of product diversification strategy on the relationship between international diversification and firm performance. Journal of World Business. 2007, Vol. 42, Iss. 1, pp. 61-79. ISSN 1090-9516. DOI: 10.1016/j.jwb.2006.11.002.

[11] CHEN, C., YU, C. Managerial ownership, diversification and firm performance: Evidence from an emerging market. International Business Review. 2011, Vol. 21, Iss. 3, pp. 518-534. ISSN 0969-5931. DOI: 10.1016/j. ibusrev.2011.06.002.

[12] CHEN, S., HO, K.W. Corporate diversification, ownership structure, and firm value the Singapore evidence. International Review of Financial Analysis. 2000, Vol. 9, Iss. 3, pp. 315-326. ISSN 1057-5219. DOI: 10.1016/ S1057-5219(00)00032-6.

[13] COLLIN, S.O., BENGTSSON, L. Corporate Governance: A strategy: A test of association between governance structures and diversification on Swedish data. Corporate Governance: An International Review. 2000, Vol. 8, Iss. 2, pp. 154-165. ISSN 1467-8683. DOI: 10.1111/1467-8683.00192.

[14] DEL BRIO, E., DE MIGUEL, A., TOBAR, J.E. Efectos de la regulación bursátil sobre la eficiencia de los mercados de valores. Comparación entre España y Reino Unido. Revista Española de Financiación y Contabilidad. 2010, Vol. 39,
Iss. 146, pp. 321-342. ISSN 0210-2412. DOI: 10.1080/02102412.2010.10779684.

[15] DEL BRIO, E., MAIA-RAMIRES, E.L., DE MIGUEL, A. Ownership structure and diversification in a scenario of weak shareholder protection. Applied Economics. 2011, Vol. 43, Iss. 29, pp. 1-11. ISSN 0003-6846. DOI: 10.1080/00036846.2010.491472.

[16] DELIOS, A., ZHOU, N., XU, W.W. Ownership structure and the diversification and performance of publicly-listed companies in China. Business Horizons. 2008, Vol. 51, Iss. 6 , pp. 473-483. ISSN 0007-6813. DOI: 10.1016/j. bushor.2008.06.004.

[17] DENIS, D.J., DENIS, D.K., SARIN, A. Agency problems, equity ownership, and corporate diversification. Journal of Finance. 1997, Vol. 52, Iss. 1, pp. 135-160. ISSN 0022-1082. DOI: 10.1111/j.1540-6261.1997. tb03811.x.

[18] DREUX, D.R. Financing family business: Alternatives to selling out or going public. Family Business Review. 1990, Vol. 3, Iss. 3, pp. 225243. ISSN 0894-4865. DOI: 10.1111/j.17416248.1990.00225.x.

[19] DUCASSY, I., PREVOT, F. The effects of family dynamics on diversified strategy: empirical evidence from French companies. Journal of Family Business Strategy. 2010, Vol. 1 , Iss. 4, pp. 224-235. ISSN 1877-8585. DOI: 10.1016/j.jfbs.2010.10.001.

[20] EISENMANN, T.R. The effects of CEO equity ownership and firm diversification on risk taking. Strategic Management Journal. 2002, Vol. 23, Iss. 6, pp. 513-534. ISSN 0143-2095. DOI: $10.1002 / \mathrm{smj} .236$.

[21] FACCIO, M., LANG, L., YOUNG, L. Dividends and Expropriation. American Economic Review. 2001, Vol. 91, Iss. 1, pp. 5478. ISSN 0002-8282. DOI: 10.1257/aer.91.1.54. [22] FAMA, E., JENSEN, M. Organizational Forms and Investment Decisions. Journal of Financial Economics. 1985, Vol. 14, Iss. 1, pp. 101-119. ISSN 0304-405X. DOI: 10.1016/0304405X(85)90045-5.

[23] FAMA, E., JENSEN, M. Agency problems and residual claims. Journal of Law and Economics. 1983, Vol. 26, pp. 301-325. ISSN 0022-2186. DOI: 10.2139/ssrn.94032.

[24] FRIEDLAND, R., PALMER, D., STENBECK, M. The geography of corporate production. Sociological Forum. 1990. Vol. 5, Iss. 3, pp. 335-359. ISSN 0884-8971. DOI: 10.1007/BF01115091. 
[25] GALÁN, J.I., SÁNCHEZ, M.J. The Continuing Validity of the Strategy-Structure Nexus: New Findings, 1993-2003. Strategic Management Journal. 2009, Vol. 30, Iss. 11, pp. 1234-1243. ISSN 0143-2095. DOI: 10.1002/ smj.782.

[26] GEDAJLOVIC, E., SHAPIRO, D. Management and ownership effects: evidence from 5 countries. Strategic Management Journal. 1998, Vol. 19, Iss. 6, pp. 533-555. ISSN 0143-2095. DOI: 10.1002/ (SICI)1097-0266(199806)19:6<533::AIDSMJ957>3.0.CO;2-\#.

[27] GEORGE, R., KABIR, R. Heterogeneity in business group and the corporate diversification firm performance relationship. Journal of Business Research. 2012, Vol. 65, Iss. 3, pp. 412-420. ISSN 0148-2963. DOI: 10.2139/ ssrn.1857923.

[28] GÓMEZ-MEJÍA, L., et al. Socioemotional wealth and business risks in family-controlled firms: Evidence from Spanish olive oil mills. Administrative Science Quarterly. 2007, Vol. 52, Iss. 1, pp. 106-137. ISSN 0001-8392. DOI: 10.2189/asqu.52.1.106.

[29] GÓMEZ-MEJÍA, L., MAKRI, M., LARRAZA, $M$. Diversification decisions in family-controlled firms. Journal of Management Studies. 2010, Vol. 47, Iss. 2, pp. 223-252. ISSN 0022-2380. DOI: 10.1111/j.1467-6486.2009.00889.x.

[30] GORANOVA, M., et al. Managerial ownership and corporate diversification: A longitudinal view. Strategic Management Journal. 2007, Vol. 28, Iss. 3, pp. 211-225. ISSN 0143-2095. DOI: 10.1002/smj.570.

[31] GOURLAY, A., SEATON, J. The determinants of firm diversification in UK. Applied Economics. 2004, Vol. 36, Iss. 18, pp. 2059-2071. ISSN 0003-6846. DOI: 10.1080/0003684042000295610.

[32] GRAHAM, J.R., LEMMON, M., WOLF, J. Does corporate diversification destroy value? Journal of Finance. 2002, Vol. 57, Iss. 2, pp. 695-720. ISSN 0022-1082. DOI: 10.1111/15406261.00439.

[33] HERNÁNDEZ, A., GALVE, C. Supervivencia y diversificación de los grupos familiares y no familiares encabezados por una empresa española cotizada en el período 19902005. Ekonomiaz: Revista Vasca de Economía. 2008, Vol. 68, pp. 182-209. ISSN 0213-3865.

[34] HOSKISSON, R.E., HITT, M.A. Antecedents and performance outcomes of diversification:Areview and critique of theoretical perspectives. Journal of Management. 1990, Vol. 16, Iss. 2, pp. 461-509. ISSN 0149-2063. DOI: $10.1177 / 014920639001600210$.

[35] HUERTA, P., NAVAS, J.E. Grado y dirección de la diversificación de las empresas industriales españolas: un análisis de la estrategia de diversificación relacionada. Revista chilena de Ingeniería. 2006, Vol. 14, Iss. 3, pp. 213-228. ISSN 0718-3291. DOI: $10.4067 / S 0718-33052006000200005$.

[36] HUERTA, P., et al. La relación entre diversificación los resultados empresariales: Un análisis empírico. Multidisciplinary Business Review. 2009, Vol. 1, Iss. 1, pp. 1-14. ISSN 0719-2118.

[37] JENSEN, M. Agency costs of free cash flow, corporate finance, and takeovers. American Economic Review. 1986, Vol. 76, Iss. 2, pp. 323-329. ISSN 0002-8282.

[38] JENSEN, M., MURPHY, K. Performance pay and top management incentives. Journal of Political Economy. 1990, Vol. 98, Iss. 2, pp. 225-263. ISSN 0022-3808.

[39] JOHNSON, S., et al. Tunneling. American Economic Review. 2000, Vol. 90, Iss. 2, pp. 2227. ISSN 0002-8282. DOI: 10.1257/aer.90.2.22. [40] JONES, C.D., MAKRI, M., GOMEZMEJIA, L.R. Affiliate directors and perceived risk bearing in publicly traded, familycontrolled firms: The case of diversification. Entrepreneurship: Theory and Practice. 2008, Vol. 32, Iss. 6, pp. 1007-1026. ISSN 10422587. DOI: 10.1111/j.1540-6520.2008.00269.x. [41] KANG, D.L. Ownership structure and the boundaries of the firm: how large-block family owners lead to increased vertical integration, diversification and superior firm performance. Academy of Management annual meeting: business policy and strategy division. January, 1999.

[42] KIM, W.C., WANG, P., BURGERS, W.P. Multinationals diversification and the risk-return trade-off. Strategic Management Journal. 1993, Vol. 14, Iss. 4, pp. 275-286. ISSN 0143-2095. DOI: $10.1002 / s m j .4250140404$.

[43] LA PORTA, R., LOPEZ DE SILANES, F., SHLEIFER, A. Corporate ownership around the world. Journal of Finance. 1999, Vol. 54, Iss. 2, pp. 471-517. ISSN 0022-1082. DOI: 10.1111/0022-1082.00115.

[44] LANE, P., CANNELLA, A., LUBATKIN, M. Ownership structure and corporate strategy: One question viewed from two different worlds. Strategic Management 
Journal. 1999, Vol. 20, Iss. 11, pp. 10771086. ISSN 0143-2095. DOI: 10.1002/ (SICI)1097-0266(199911)20:11<1077:AIDSMJ68>3.0.CO;2-O.

[45] LARRAZA, M., GÓMEZ-MEJÍA, L.R., MAKRI, M. Propiedad familiar, participación accionarial del consejero delegado $y$ diversificación. Congreso ACEDE, Murcia, 2004.

[46] LEE, J. Family firm performance: Further evidence. Family Business Review. 2006, Vol. 19, Iss. 2, pp. 103-114. ISSN 0894-4865. DOI: 10.1111/j.1741-6248.2006.00060.x.

[47] LINS, K., SERVAES, H. Is corporate diversification beneficial in emerging markets? Financial Management. 2002, Vol. 31, Iss. 2, pp. 5-32. ISSN 0046-3892. DOI: 10.2139/ ssrn.282419.

[48] LUBATKIN, M., MERCHAN, H., SRINIVASAN, N. Construct validity of some unweighted product-count diversification measures. Strategic Management Journal. 1993, Vol. 14, Iss. 6, pp. 433-449. ISSN 01432095. DOI: $10.1002 / \mathrm{smj} .4250140604$.

[49] MARTIN, J.D., SAYRAK, A. Corporate diversification and shareholder value. Journal of Corporate Finance. 2003, Vol. 9, Iss. 1, pp. 37-57. ISSN 0929-1199. DOI: 10.1016/S09291199(01)00053-0.

[50] MARTÍNEZ, A., FERNÁNDEZ, R. Impacto de la estrategia de diversificación en el resultado empresarial: ¿influye el estilo de comportamiento del CEO que diversifica? Revista Europea de Dirección y Economía de la Empresa. 2008, Vol. 17, Iss. 3, pp. 111-132. ISSN 1019-6838.

[51] MAY, D.O. Do managerial motives influence firm risk reduction strategies? Journal of Finance. 1995, Vol. 50, Iss. 4, pp. 12911308. ISSN 0022-1082. DOI: 10.1111/j.15406261.1995.tb04059.x.

[52] MAZZI, C. Family business and financial performance: Current state of knowledge and future research challenges. Journal of Family Business Strategy. 2011, Vol. 2, Iss. 3, pp. 166-181. ISSN 1877-8585. DOI: 10.1016/j. jfbs.2011.07.001.

[53] MENARD, S. Quantitative Applications in the Social Sciences. 2nd ed. Thousand Oaks: Sage Publications, Longitudinal Research, 2002. ISBN 0-80395757-2.

[54] MILLER, D., LE BRETON-MILLER, I. Agency vs. stewardship in public family firms: a social embeddedness reconciliation.
Entrepreneurship: Theory and Practice. 2009, Vol. 33, Iss. 6, pp. 1169-1191. ISSN 1042-2587. DOI: 10.1111/j.1540-6520.2009.00339.x.

[55] MILLER, D., LE BRETON-MILLER, I., LESTER, R.H. Family Ownership and Acquisition Behavior in Publicly-Traded Companies. Strategic Management Journal. 2010, Vol. 31, Iss. 2, pp. 201-214. ISSN 01432095. DOI: $10.1002 / \mathrm{smj} .802$.

[56] MILLER, R.A. Concentration and marginal concentration, advertising and diversity: Three issues structure performance tests. Industrial Organization Review. 1973, Vol. 1, Iss. 1, pp. 15-24. ISSN 0194-2875.

[57] MONTGOMERY, C. Product-market diversification and market power. Academy of Management Journal. 1985, Vol. 28, Iss. 4, pp. 789-798. ISSN 0001-4273. DOI: 10.2307/256237.

[58] MUÑOZ-BULLÓN, F., SÁNCHEZ-BUENO, M.J. Do family ties shape the performance consequences of diversification? Evidence form the European Union. Journal of World Business. 2011, Vol. 47, Iss. 3, pp. 469-477. ISSN 10909516. DOI:10.1016/j.jwb.2011.05.013.

[59] NEWBOUND, G., BUCKLEY, P., TURWELL, J. Going international: The experience of smaller companies overseas. Somerset, NJ: Halstead Press, 1978.

[60] PALEPU, K. Diversification strategy, profit performance and the entropy measure. Strategic Management Journal. 1985, Vol. 6, Iss. 3, pp. 239-255. ISSN 0143-2095. DOI: 10.1002/smj.4250060305.

[61] PALICH, L.E., CARDINAL, L.B., MILLER, C.C. Curvilinearity in the diversificationperformance linkage: An examination of over three decades of research. Strategic Management Journal. 2000, Vol. 21, Iss. 2, pp.155-174. ISSN 0143-2095. DOI: 10.1002/ (SICI)1097-0266(200002)21:2<155::AIDSMJ82>3.0.CO;2-2.

[62] PALLANT, J. SPSS survival manual: a step by step guide to data analysis using SPSS. Glasgow: Allen and Unwin editorial, 2007. ISBN 0-335-22366-4.

[63] RAMASWAMY, K., LI, M., VELIYATH, R. Variations in ownership behaviour and propensity to diversify: a study of the Indian corporate context. Strategic Management Journal. 2002, Vol. 23, Iss. 4, pp. 345-358. ISSN 1097-0266. DOI: 10.1002/smj.227.

[64] RUMELT, R.P. Diversification strategy and profitability. Strategic Management Journal. 
1982, Vol. 3, Iss. 4, pp. 359-369. ISSN 01432095. DOI: $10.1002 / s m j .4250030407$.

[65] RUMELT, R.P. Strategy, structure and economic performance. Boston: Harvard University Press, 1974. ISBN 0875841090.

[66] SHACKMAN, J.D. Corporate diversification, vertical integration and internal capital markets: Across-country study. Management International Review. 2007, Vol. 47, Iss. 4, pp. 479-504. ISSN 0938-8249. DOI: 10.1007/s11575-007-0027-z.

[67] SHLEIFER, A., VISHNY, R. A survey of corporate governance. Journal of Finance. 1997, Vol. 52, Iss. 2, pp. 737-783. ISSN 0022-1082. DOI: 10.1111/j.1540-6261.1997. tb04820.x.

[68] SHLEIFER, A., VISHNY, R. Large shareholders and corporate control. Journal of Political Economy. 1986, Vol. 94, Iss. 3, pp. 461-488. ISSN 0022-3808.

[69] VARADARAJAN, P., RUMANUJAM, V. Diversification and performance: $A$ reexamination using a new two-dimensional conceptualization of diversity in firms. Academy of Management Journal. 1987, Vol. 30, Iss. 2, pp. 380-393. ISSN 0001-4273. DOI: 10.2307/256281.

[70] VILLALONGA, B. Does diversification cause the 'diversification discount'? Financial Management. 2004, Vol. 33, Iss. 2, pp. 5-27. ISSN 0046-3892.

[71] VILLALONGA, B., AMIT, R. How do family ownership, control and management affect firm value? Journal of Financial Economics. 2006, Vol. 80, Iss. 2, pp. 385-417. ISSN 0304-405X. DOI: 10.1016/j.jfineco.2004.12.005.

[72] WAN, W.P., et al. Resource-based theory and corporate diversification: accomplishments and opportunities. Journal of Management. 2011, Vol. 37, Iss. 5, pp. 1335-1368. ISSN 0217-4561. DOI: 10.1177/0149206310391804. [73] WILLIAMSON, O. Markets and hierarchies: analysis and antitrust implications. New York: The Free Press, 1975. ISBN 0029347807.

[74] YOUNG, M., et al. Governing the corporation in emerging economies: a review of the principal-principal perspective. Journal of Management Studies. 2008, Vol. 45, Iss. 1, pp. 196-220. ISSN 1467-6486. DOI: 10.5465/ APBPP.2002.7516497.

[75] ZAHRA, S.A. Entrepreneurial risk taking in family firms. Family Business Review. 2005, Vol. 18, Iss. 1, pp. 23-40. ISSN 0894-4865. DOI: 10.1111/j.1741-6248.2005.00028.x.

[76] ZHANG, Y., LI, X. Ownership structure and corporate diversification. Business and Politics. 2006, Vol. 8, Iss. 1, pp. 1-19. ISSN 1469-3569. DOI: 10.2202/1469-3569.1144.

[77] ZOZAYA, N. Las fusiones y adquisiciones como formula de crecimiento empresarial. Dirección General de Política de la Pyme. Ministerio de Industria y Turismo, 2007.

Prof. Alejandro Hernández-Trasobares, Ph.D. University of Zaragoza Faculty of Social and Work Sciences Management Department alex@unizar.es

Prof. Carmen Galve-Górriz, Ph.D. University of Zaragoza Faculty of Business and Economics Management Department cgalve@unizar.es 


\section{Abstract}

\section{DOES CONCENTRATION OF OWNERSHIP AND FAMILY CONTROL AFFECT SPECIALISATION/DIVERSIFICATION BUSINESS STRATEGIES?}

\section{Alejandro Hernández-Trasobares, Carmen Galve-Górriz}

The impact of family ownership on strategic decision-making and diversification in public corporations is an important but not clearly understood aspect of modern corporate governance. In many cases, large-block family owners of public corporations may have a great deal of input in strategic decision-making in large corporations. Previous literature investigates how ownership structure and diversification are connected, but conclusions are not homogeneous. Agency theory suggests that professional managers are fundamentally self-interested, and the public corporation diversifies because managers pursue their own interests, rather than the interest of shareholders. However in family firms, ownership and control use to coincide and family diversification decisions which causes a lower diversification. In this paper authors analyzes the impact of ownership concentration and the influence of ultimate owner's nature of business group (family or non-family) in diversification's decision: specialization, related diversification, unrelated diversification and mixed diversification (when a company uses both related and unrelated diversification) Based on a sample of ninety-nine Spanish listed companies during the years 2000-2005, and using the listed company an their subsidiaries (pyramidal group) as unit of analysis, this research finds: firstly, the highest ownership concentration increases the adoption of specialization strategies and reduce the mixed diversification; Secondly, attending to ultimate owner's nature, family firms adopt more strategies of specialization and related diversification, and less diversification strategies than nonfamily firms; Finally, results also show behaviour differences in family firms according to ownership concentration's degree: an increasing ownership concentration's degree in family firms rises the probability of diversification.

Key Words: Family firm, specialization, diversification, ultimate owner, corporate governance.

JEL Classification: M19, M20, G32, G34.

DOI: 10.15240/tul/001/2015-4-006 